\title{
A Estrutura Multiplicativa no Ensino Fundamental Baiano: Um projeto de sucesso em larga escala
}

\section{Sandra Maria Pinto Magina}

Organizadora/Editora deste número temático da revista "Com a palavra, o professor"

Este número apresenta para a comunidade da Educação Matemática o projeto, financiado pela FAPESB (Termo de outorga PES 0019/2013), intitulado “As Estruturas Multiplicativas e a formação de professores que ensinam Matemática na Bahia”. Ele foi desenvolvido em oito diferentes localidades baianas, no âmbito de seis núcleos: Ilhéus, Itabuna e São José da Vitória (Núcleo sede UESC), Vitória da Conquista (Núcleo UESB), Amargosa (Núcleo UFRB), Feira de Santana (Núcleo UESB/NEEMFS), Salvador (Núcleo EMFoco) e Nosso Senhor do Bonfim (Núcleo UNEB) entre os anos de 2013 e 2017. O objetivo de tal projeto foi investigar a prática dos professores no ensino das Estruturas Multiplicativas, baseados no modelo de formação "reflexão-planejamento-ação-reflexão" (RePARe) do professor (MAGINA, 2008; MAGINA, MERLINI, SANTOS, 2012), com vistas a avaliar o desenvolvimento de estratégias de ensino que possibilitem a expansão e apropriação deste Campo Conceitual pelos estudantes. O aporte teórico foi a Teoria dos Campos Conceituais, com ênfase no campo conceitual multiplicativo, ou, simplificadamente, as estruturas multiplicativas. Para tanto utilizou-se a releitura proposta por Magina, Santos e Merlini (2014).

A metodologia do projeto previu inicialmente a aplicação de um instrumento diagnóstico, contendo situações-problema das estruturas multiplicativas, nos estudantes dos professores que participaram da formação continuada. Responderam ao instrumento 4.076 estudantes, enquanto 158 professores participaram da formação. Os resultados dos desempenhos dos estudantes foram analisados e constantemente utilizados, de maneira fatiada, ao longo da formação dos professores.

Muitas dissertações e muitos artigos foram publicados, pelos membros dos seis núcleos, ao longo do projeto. Neste número apresentaremos sete artigos, todos apresentando um olhar sobre parte dos dados produzidos pelo projeto, sendo que seis focaram os estudantes, e um os professores.

Assim, o artigo "As estruturas multiplicativas e a formação de professores que ensinam matemática na Bahia: um projeto de larga escala”, escrito por Magina, Santana e Cazorla, oferece uma contundente discussão sobre a base teórica do projeto, tanto no que tange 
ao Campo Conceitual das Estruturas Multiplicativas, quanto sobre o modelo metodológico de formação de professor RePARe. Já no artigo "Desempenho de estudantes baianos nas estruturas multiplicativas: uma visão quantitativa dos fatos”, de autoria de Magina e Fonseca, é apresentado um panorama geral dos desempenhos dos 4076 estudantes nas 14 situaçõesproblema do instrumento diagnóstico. Na sequência, o artigo elaborado por Merlini e Teixeira discute o desempenho dos estudantes do $1^{\circ}$ ano no que tange ao conceito de proporcionalidade (As estratégias de resolução dos estudantes de $1^{0}$ ano em situações de proporção simples"). Esse mesmo conteúdo - a proporcionalidade - é retomado por Oliveira, Santana e Silva ("As resoluções de estudantes em situações de proporção simples”), agora focando os $3^{\circ}$ e $5^{\circ}$ anos. Ainda sobre o tema proporcionalidade, diferentemente dos demais artigos deste número, Luna, Figueiredo e Lima focam na produção de estudantes do $5^{\circ}$ ano ao resolverem situaçõesproblema envolvendo a proporção simples em atividades por uma professora, que participou da formação, dentro de sua sala de aula ("Textos produzidos pelas crianças ao resolverem situações-problema envolvendo o eixo proporção simples com a classe muitos para muitos”). Fechando o tema proporcionalidade, Teixeira, Silva Filho e Merlini, escrevem um artigo comparando os desempenhos dos estudantes do último ano dos anos iniciais e com estudante do último ano dos anos finais do Ensino Fundamental ("O desempenho de estudantes do $5^{\circ} \mathrm{e}$ $9^{\circ}$ anos frente a situações de proporção simples: uma análise comparativa”). Por fim Barbosa e Oliveira encerram este número especial escrevendo sobre as estratégias de alunos do $7^{\circ}$ ano ao lidarem com as situações-problema do diagnóstico que envolveram o conceito de produto de medidas ("Produto de medidas: analisando as estratégias de resolução de problemas de estudantes do $7^{\circ}$ ano do ensino fundamental").

O conjunto dos artigos aqui apresentados oferece uma boa visão sobre as contribuições que o Projeto “As Estruturas Multiplicativas e a Formação de Professores Baianos" (FAPESB, PESoo19/2013) trouxe para o nosso entendimento de como estudantes baianos, dos diversos anos escolares do ensino Fundamental, lidam e entendem as estruturas multiplicativas.

Desejo a todos uma boa leitura! 